\title{
A Clinico-pathological Study of Colo-rectal Atresia
}

\section{Pankaj Halder ${ }^{1 *}$, Rajarshi Kumar ${ }^{2}$, Kartik Chandra Mandal ${ }^{1}$, Gobinda Mondal ${ }^{3}$, Bidyut Debnath ${ }^{1}$, Biswanath Mukhopadhyay ${ }^{4}$ and Bikram Mandal ${ }^{3}$}

${ }^{1}$ Department of Pediatric Surgery, Dr. B.C. Roy, Post Graduate Institute of Pediatric Sciences (PGIPS), Kolkata, West Bengal, India

${ }^{2}$ Department of Pediatric Surgery, Institute of Post-Graduate Medical Education and Research (IPGMER), Kolkata, West Bengal, India

${ }^{3}$ Department of Pediatric Medicine, Dr. B.C. Roy, Post Graduate Institute of Pediatric Sciences (PGIPS), Kolkata, West Bengal, India

${ }^{4}$ Department of Pediatric Surgery, Nil Ratan Sircar Medical College and Hospital, Kolkata, West Bengal, India

${ }^{*}$ Corresponding author: Pankaj Halder, Department of Pediatric Surgery, Dr. B.C. Roy, Post Graduate Institute of Pediatric Sciences (PGIPS), Saroda pally, Baruipur, Kolkata, West Bengal, India, Tel: 09231798777; E-mail: pankaj.cnmc@gmail.com

Rec date: Oct 03, 2017; Acc date: Nov 03, 2017; Pub date: Nov 05, 2017

Citation: Halder P, Kumar K, Mandal K, Mondal G, Debnath B, et al. (2017) A Clinico-pathological Study of Colo-rectal Atresia. Ped Health Res Vol.2:No.3:15

\section{Abstract}

Background: For colorectal atresia, single stage operative procedure become more and more popular in many tertiary care center, especially, where frozen section biopsy is available. In this study, we aimed to highlight our experiences with seven cases colorectal atresias which were managed successfully with staged operative procedure in our institution during last 4 years.

Methods: A prospective study of colorectal atresia involved 7 patients (5 colonic atresias and 2 rectal atresias) admitted in a teaching hospital between June 1 , 2013, and April 30, 2017. All patients were properly evaluated for associated anomalies before subjecting them to the final stage surgery (colostomy closure). The patients' demographics, presenting symptoms, diagnostic studies, treatment options and complications, average length of hospital stay, time taken to complete the final surgery, associated anomalies and its managements and histopathology reports of rectal biopsy were considered.

Results: Five colonic atresias were treated by initial colostomy and rectal tissue biopsy then colostomy closure (two stage). Rectal atresias were treated by colostomy followed by posterior sagittal anorectoplasty then colostomy closure (three stage). One of the colonic atresia cases was associated with annular pancreas. One rectal atresia case was associated with presacral dermoid and rectovaginal fistula. None of our patients had associated Hirschsprung's disease.

Conclusion: Timely diagnosis and management can be made if this condition is kept in mind while treating a case of neonatal intestinal obstruction. Single staged surgery should be avoided when emergency exploration is undertaken for intestinal obstruction. Irrespective of type of the atresia, staged surgery is most viable option for fruitful outcome, especially in developing countries.

\section{Keywords: Colon; Atresia; Colostomy; Rectum;}

Hirschsprung's disease

Abbreviations: USG-KUB: Ultrasonography of Kidney Ureter and Bladder; 2D Echo: Two-Dimensional Echocardiography; MCU: Micturating Cystourethrography; PSARP: Posterior Sagittal Anorecto Plasty; NAD: No Abnormality Detected; UGI: Upper Gastro-Intestinal

\section{Introduction}

Colonic atresia (CA) comprises $1.8 \%$ to $15 \%$ of all intestinal atresias and occurs in descending order of frequency at sigmoid, splenic flexure, hepatic flexure and ascending colon respectively [1]. Rectal atresia (RA) is extremely rare, contributing ( $1 \%$ to $2 \%)$ of total anorectal malformation (ARM). Both CA and RA present with intestinal obstruction usually, in neonatal period. RA can be diagnosed by clinical examination alone (inability to pass a rubber catheter in the rectum beyond 2-3 $\mathrm{cm}$ [2]. On the other hand, features of CA mimic with the other common entities of neonatal intestinal obstruction, especially of Hirschsprung's disease (HD). Colorectal atresias are usually treated by staged operation (two stages for colonic atresia and three stages for rectal atresia). The strategy of surgical intervention varies depending on the age of the patient, time of diagnosis, luminal disparity between proximal and distal bowel, general condition of the patient and associated congenital anomalies like; HD [3].

\section{Materials and Methods}

This is a scrutiny of 7 cases of CRA ( 5 cases of CA and 2 cases of RA), which were successfully managed in our institute during last four years. Five CA underwent two stages surgical intervention (colostomy and rectal biopsy-colostomy closure) and two RA underwent three stages surgical intervention (colostomy and biopsy-posterior sagittal anorectoplastycolostomy closure) in treatment of their disease. The patients data in the form of their demographic profile, clinical 
presentations, investigations [(X-ray, Contrast enema study, ultrasonography (USG), Echocardiography, micturating cystourethrogram (MCU)], associated congenital anomalies (if any) and surgical intervention for it, management algorithm and prognosis were collected, tabulated and analysed (Table 1).

\section{Results}

Least age to get operated was baby of 1 day and most 8 months. 4 were females (57.14\%), most common presentation was acute intestinal obstruction requiring emergency laparotomy followed by colostomy and rectal biopsy. Out of 5 cases of CA, 3 had descending colonic atresia, 1 had atresia at hepatic flexure and 1 had transverse colonic atresia. All of them had type 1 atresia (membrane). 2 cases of CA (atresia at hepatic flexure and atresia at descending - sigmoid junction) were detected only after emergency exploratory. Other 3 cases of CA (atresia at descending colon and atresia at transverse colon) were successfully diagnosed based on preoperative investigations (Figures 1 and 2). In all cases of CA, colostomy and full thickness rectal biopsy were performed during initial surgical procedure. One patient with CA had associated annular pancreas (AP) which we which was treated by duodeno-duodenostomy successfully. All 5 cases of colonic atresia underwent two stage operations as, none had associated HD.

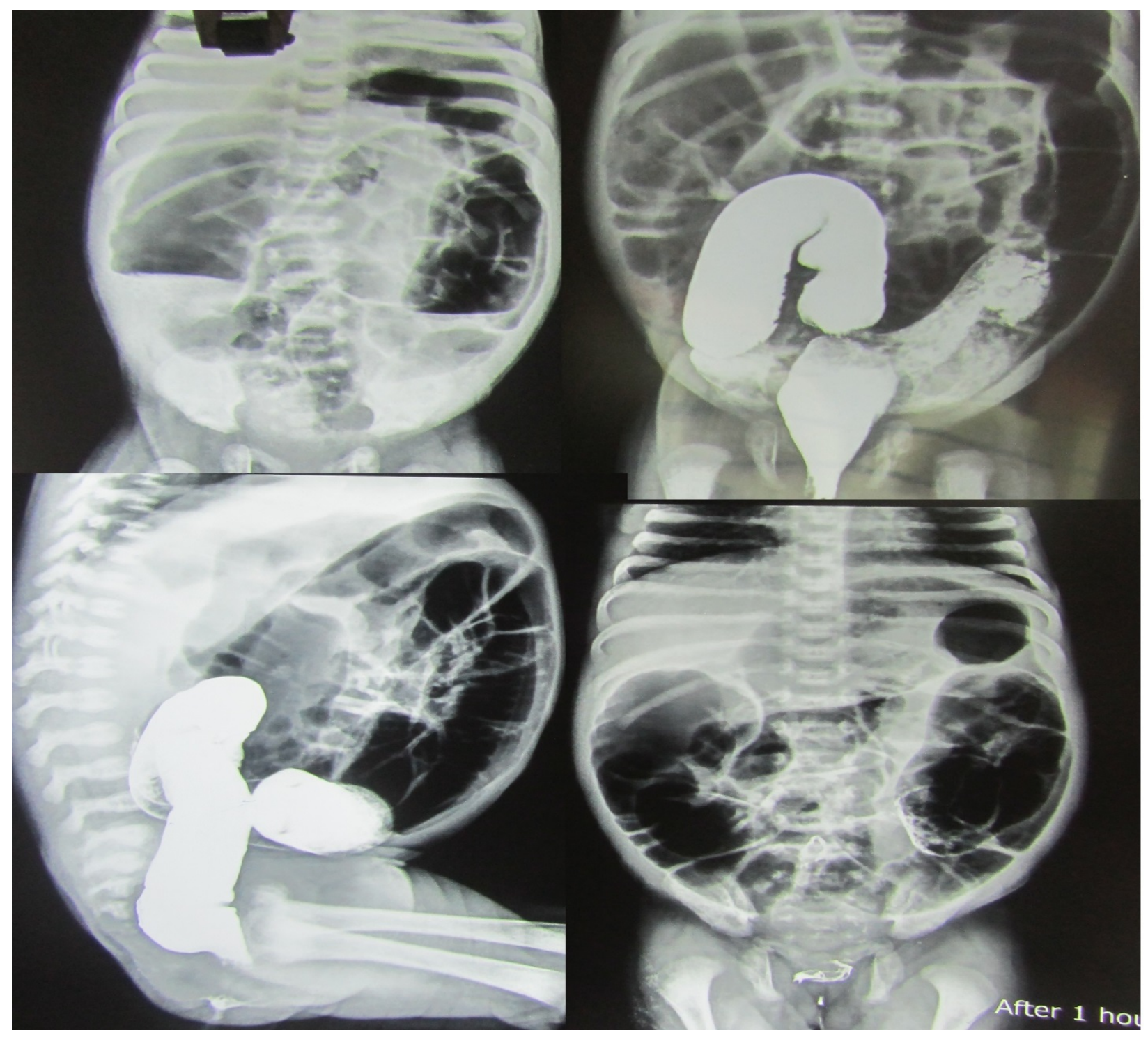

Figure 1 Contrast enema study shows contrast filled lumen of the distal colon, terminating at a point adjacent to the segment that is most distended with luminal air - The cut-off point.

Two cases of RA were encountered in this study. Both of them had type 1 RA. One patient presented with a sigmoid colostomy (divided). She was initially diagnosed as rectovaginal fistula and underwent colostomy in a private hospital.
During posterior sagittal anorectoplasty (PSARP), a rectal membrane (type 1 RA) was detected. The membrane was excised in addition to repair of recto-vaginal fistula. This patient also had a presacral dermoid which was operated in a 
separate occasion. Second one was referred from a rural hospital as a suspected case of RA with status colostomy. Here also we had found a rectal membrane (type $1 \mathrm{RA}$ ) which was excised during PSARP. Colostomy closure was performed after 6 weeks of PSARP. None of our patients had associated HD. All the patients recovered quickly after initial colostomy. None of them had stoma related complications. And due to early reversal of stoma, there was no major disparity between the caliber of proximal and distal stoma. There were no major perioperative complications or mortality in this study.

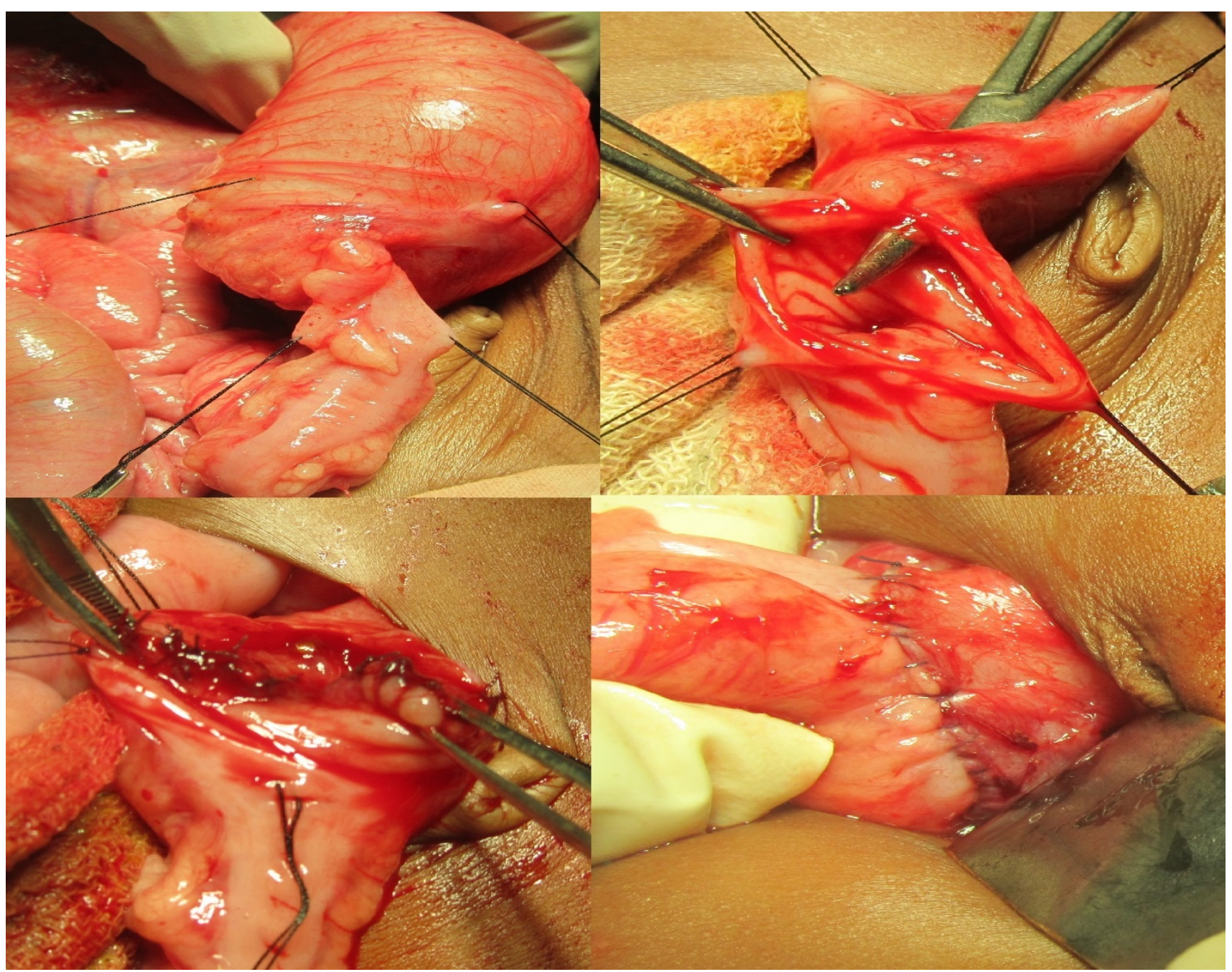

Figure 2 Intra-operative picture shows an intraluminal membrane (type 1 atresia) at descending colon, excision and primary colo-colic anastomosis.

\section{Discussion}

The CRA present with a considerable challenge to the clinicians. CA was first reported early in 1673 by Binniger while the first survivor of CA with colostomy was reported by Gaub in 1922.

Exact etiology of CA is still unclear. Widely accepted theory is that of vascular insult owing to embolus in the mesenteric artery, internal herniation, kinks, intussusception and maternal use of cocaine in the early gestation. Recently, "two-point constriction" theory has gained popularity as it does explain multiple intestinal atresias in patient with gastroschisis. According to this theory, the intestinal atresia occurs due to bowel compression with the narrow abdominal wall defect. Pujar et al. proposed recanalization failure theory for intestinal atresia which also scientifically justifies the association of pyloric atresia with CA [4]. Other possible hypothesis is colonic volvulus, incarceration and strangulation of internal hernias inutero, intestinal perforation in -utero, drugs, fetal infection with varicella and environmental factors. A few cases of familial CA have been reported in literature also.

CA is frequently associated with one or more congenital anomalies like; anterior abdominal wall defect, bladder exstrophy, other alimentary tract atresia/stenosis, vesicointestinal fistula, malfixation of the mesentery, $\mathrm{HD}(0.2 \%$ to $0.8 \%)$, musculoskeletal disorders, ocular and facial anomalies, pyloric atresia, choledochal cyst and annular pancreas [5]. In this study, two cases (28.57\%) were associated with other congenital anomalies (CA with AP and RA with presacral dermoid). Thus, systemic and meticulous investigations are necessary for screening of associated anomalies. 
The patients with CRA usually present with vomiting, abdominal distention and inability to pass meconium or passage of only small amount of meconium. The condition must be differentiated from other causes of neonatal intestinal obstruction like; meconium plug syndrome, short colon syndrome, micro colon, terminal ileal atresia colonic stenosis (CS) and HD. CS is even rarer than atresias and can be congenital or acquired [6]. Sometimes, symptoms are superimposed by the presence of one or more associated congenital anomalies. Unlike CA, RA can be diagnosed clinically by passing a red rubber catheter through rectum. In case of RA, a per-rectal catheter could not be negotiated beyond $5 \mathrm{~cm}$. Similar difficulty may be encountered in meconium plug syndrome also. Recto-urinary fistula or recto vestibular fistula may be associated with RA. In these circumstances, proper diagnosis of RA is difficult. In this study, one of the RA case was initially misdiagnosed as vestibular fistula. And, during PSARP, type 1 RA was detected in addition to recto-vestibular fistula.

Table 1 Clinical spectrum of colo-rectal atresias.

\begin{tabular}{|c|c|c|c|c|c|c|c|}
\hline No & $\begin{array}{l}\text { Age, sex } \\
\text { and weight }\end{array}$ & Presentation & Investigations & $\begin{array}{l}\text { Associated } \\
\text { anomalies }\end{array}$ & $\begin{array}{l}\text { Operative } \\
\text { findings }\end{array}$ & $\begin{array}{l}\text { Operative } \\
\text { procedure }\end{array}$ & Follow-up \\
\hline 1 & $\begin{array}{l}\left(\begin{array}{l}1 \\
\mathrm{~d}\end{array} \mathrm{10}\right. \\
\mathrm{d} / \mathrm{F} / 2.28 \\
\mathrm{Kg}\end{array}$ & $\begin{array}{l}\text { Sub-acute } \\
\text { intestinal } \\
\text { obstruction }\end{array}$ & $\begin{array}{l}\text { Contrast enema study- no } \\
\text { HD but narrowing at } \\
\text { sigmoid- descending } \\
\text { junction. X-ray, USG, } 2 \text { D } \\
\text { Echo- NAD. }\end{array}$ & No & $\begin{array}{l}\text { Web with } \\
\text { eccentric } \\
\text { perforation at } \\
\text { sigmoid- } \\
\text { descending } \\
\text { colon junction. }\end{array}$ & $\begin{array}{l}\text { Excision of the web } \\
\text { and primary } \\
\text { anastomosis with } \\
\text { proximal diverting } \\
\text { right transverse } \\
\text { colostomy ry in } \\
\text { addition to rectal } \\
\text { biopsy. }\end{array}$ & $\begin{array}{l}\text { Biopsy- Normal. } \\
\text { Colostomy } \\
\text { closure after } 6 \\
\text { weeks. } 2 \text { years } \\
\text { follow-up the } \\
\text { patient is } \\
\text { symptom-less. }\end{array}$ \\
\hline 2 & $\begin{array}{l}4 \mathrm{~d} / \mathrm{F} / 2.5 \\
\mathrm{Kg}\end{array}$ & $\begin{array}{l}\text { Constipation } \\
\text { since birth, } \\
\text { vomiting, } \\
\text { abdominal } \\
\text { distension. P/R- } \\
\text { scanty meconium }\end{array}$ & \begin{tabular}{lcr} 
Contrast & \multicolumn{2}{c}{ enema-narrow } \\
sigmoid colon and no \\
evidence of HD. X-ray, \\
USG, & 2 & D \\
Echocardiography- NAD
\end{tabular} & No & $\begin{array}{l}\text { Type II atresia at } \\
\text { descending } \\
\text { colon }\end{array}$ & $\begin{array}{l}\text { Descending } \\
\text { colostomy with a } \\
\text { rectal biopsy. }\end{array}$ & $\begin{array}{l}\text { Biopsy-Normal. } \\
\text { Colostomy } \\
\text { closure done after } \\
7 \text { weeks. The } \\
\text { patient was ok at } \\
3 \text { year follow-up. }\end{array}$ \\
\hline 3 & $\begin{array}{l}1 \mathrm{~d} / \mathrm{M} / 2.6 \\
\mathrm{Kg}\end{array}$ & $\begin{array}{lr}\text { Not } & \text { passed } \\
\text { meconium since } & \text { silious } \\
\text { birth. } & \text { Biling, } \\
\text { vomiting, } \\
\text { abdominal } \\
\text { distension. }\end{array}$ & $\begin{array}{l}\text { X-ray- multiple air fluid } \\
\text { level but no free air under } \\
\text { diaphragm. USG- NAD }\end{array}$ & No & $\begin{array}{l}\text { Colonic atresia } \\
\text { at the level of } \\
\text { hepatic flexure. }\end{array}$ & $\begin{array}{l}\text { (R) Transverse } \\
\text { colostomy with } \\
\text { rectal biopsy. Distal } \\
\text { colonic patency } \\
\text { checked by normal } \\
\text { saline wash. }\end{array}$ & $\begin{array}{l}\text { Biopsy -normal. } \\
\text { Colostomy } \\
\text { closure after } 6 \\
\text { weeks. On } 3 \text { year } \\
\text { follow-up patient } \\
\text { was fine. }\end{array}$ \\
\hline 4 & $\begin{array}{l}2 \mathrm{~d} / \mathrm{F} / 2.2 \\
\mathrm{Kg}\end{array}$ & $\begin{array}{l}\text { Not passed } \\
\text { meconium since } \\
\text { birth. P/R } \\
\text { catheter could not } \\
\text { be negotiated } \\
\text { beyond } 5 \mathrm{~cm} \text {. }\end{array}$ & $\begin{array}{l}\text { X-ray- Distended gut } \\
\text { loops with absence of gas } \\
\text { shadow in pelvic region. } \\
\text { USG- NAD }\end{array}$ & $\begin{array}{l}\text { Annular } \\
\text { pancreas. }\end{array}$ & $\begin{array}{l}\text { Colonic atresia } \\
\text { at transverse } \\
\text { colon. (Annular } \\
\text { pancreas on re- } \\
\text { exploration due } \\
\text { to upper Gl } \\
\text { obstruction). }\end{array}$ & $\begin{array}{l}\text { Transverse } \\
\text { colostomy with } \\
\text { rectal biopsy at } \\
\text { initial operation. } \\
\text { Re-exploration was } \\
\text { done after } 3 \text { weeks } \\
\text { because of } \\
\text { duodenal } \\
\text { obstruction (annular } \\
\text { pancreas) and duo- } \\
\text { duodenostomy } \\
\text { done. }\end{array}$ & $\begin{array}{l}\text { Biopsy- Normal. } \\
\text { Colostomy } \\
\text { closure was done } \\
\text { after } 8 \text { weeks. At } \\
3 \text { year follow-up } \\
\text { the patient was } \\
\text { doing well }\end{array}$ \\
\hline 5 & $\begin{array}{l}21 \mathrm{~d} / \mathrm{M} / 1.5 \\
\mathrm{~K} \\
\mathrm{~g}\end{array}$ & $\begin{array}{l}\text { Constipation } \\
\text { since birth with } \\
\text { abdominal } \\
\text { distension. P/R- } \\
\text { scanty stool. }\end{array}$ & $\begin{array}{l}\text { Contrast enema study } \\
\text { showed luminal narrowing } \\
\text { at the level of descending } \\
\text { colon and no evidence of } \\
\text { HD. }\end{array}$ & No & $\begin{array}{l}\text { Colonic atresia } \\
\text { at the level of } \\
\text { descending- } \\
\text { sigmoid junction. }\end{array}$ & $\begin{array}{lr}\text { Sigmoid } & \text { loop } \\
\text { Colostomy } & \text { and } \\
\text { rectal biopsy } & \text { done. }\end{array}$ & $\begin{array}{l}\text { Biopsy normal. } \\
\text { Patient is waiting } \\
\text { for colostomy } \\
\text { closure }\end{array}$ \\
\hline 6 & $\begin{array}{l}8 \mathrm{~m} / \mathrm{F} / 6.8 \\
\mathrm{Kg}\end{array}$ & $\begin{array}{l}\text { Constipation } \\
\text { since birth. } \\
\text { Diagnosed as } \\
\text { perineal canal. }\end{array}$ & $\begin{array}{l}\text { USG KUB, MCU, Echo- } \\
\text { normal }\end{array}$ & $\begin{array}{l}\text { Presacral } \\
\text { dermoid, } \\
\text { Recto-vaginal } \\
\text { fistula }\end{array}$ & $\begin{array}{l}\text { During PSARP, } \\
\text { type } 1 \text { RA was } \\
\text { found. }\end{array}$ & 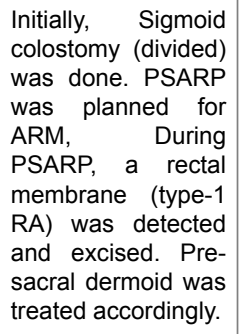 & $\begin{array}{lr}\begin{array}{lr}\text { Colostomy } \\
\text { closure }\end{array} & \text { was } \\
\text { undertaken } & 6 \\
\text { weeks } & \text { after } \\
\text { PSARP. } & \text { No } \\
\text { operative } & \\
\text { procedure } & \text { related } \\
\text { complication. }\end{array}$ \\
\hline 7 & $\begin{array}{l}3 \mathrm{~m} / \mathrm{M} / 5.5 \\
\mathrm{Kg}\end{array}$ & $\begin{array}{l}\text { Referred from } \\
\text { regional hospital } \\
\text { with colostomy in } \\
\text { a suspected case } \\
\text { of RA }\end{array}$ & 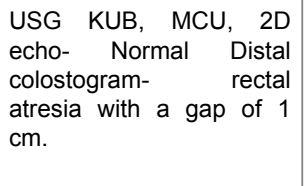 & No & $\begin{array}{l}\text { Type } 1 \text { RA was } \\
\text { identified during } \\
\text { PSARP. }\end{array}$ & $\begin{array}{l}\text { PSARP with } \\
\text { excision of rectal } \\
\text { membrane (type } 1 \\
\text { RA). }\end{array}$ & $\begin{array}{l}\text { Colostomy } \\
\text { closure was done } \\
\text { after } 6 \text { weeks of } \\
\text { PSARP. At } 4 \text { year } \\
\text { follow-up the } \\
\text { patient was ok. }\end{array}$ \\
\hline
\end{tabular}


Prenatal ultrasound can recognize CRA by presence of colonic haustra and coursing of the colon at the periphery of the abdomen. Postnatally, plane X-ray of abdomen typically shows dilated gut loops and multiple air fluid level with absence or scanty gas shadow in pelvic region. Similar X-ray findings may be seen in HD. Water soluble contrast enema study has in important role in diagnosing the CRA but care must be taken to avoid unnecessary gut perforation during the procedure [7]. Depending on the contrast study findings, Bland-Sutton described three types of colonic atresia. Type I CA where an obstructing intraluminal membrane is present. The typical "Wind sock" sign is found in contrast enema study. In type II CA, the proximal and distal colonic ends are connected by a cordlike remnant whereas in type III, both the ends are completely separated. During contrast study, the contrast will typically fill the lumen of distal unused colon, terminating at a point adjacent to the segment that is most distended with luminal air (air-contrast cut-off point). A hook sign may be found in type III CA and abrupt termination of the opacified colon is seen in both types II and III CA. In case of CS, the contrast enema study shows a distal unused colon (small caliber) and proximal distended colon (large caliber) [8]. Sometimes, this finding is confusing with HD. But, associated HD cannot be ruled out because of absence of the specific cone is not likely to be present in distal unused colon. Thus, rectal biopsy is recommended in each cases of CA for exclusion of associated HD. A revised classification of rectal atresia was described recently [9]. Type I: Rectal stenosis, type II: Rectal atresia with a septal defect, type III: RA with a fibrous cord between the atretic ends, type IV: RA with a gap, type V: (a) Multiple atresia with stenosis, (b). Multiple atresia.

The management strategy of CA depends several factors; general condition of the patient, timing of the diagnosis, associated congenital anomalies and available facilities for the frozen section biopsy (FSB). The first primary anastomosis was performed by Potts in a case of transverse CA in 1947 and the baby survived. The primary colo-colic anastomosis is considered only where FSB is available. Limiting factors of primary anastomosis or single stage surgery are proximal colonic perforation and gross disparity between proximal and distal colon. Initial Proximal colostomy with a rectal tissue biopsy serves both early recovery and exclusion of associated HD. Moreover, a thorough screening for associated anomalies and normalisation of gross disparity between proximal and distal colon is possible during this period [10].

In right transverse colonic atresia, due to hugely dilated caecum and the enormous disparity between the caecum and atretic transverse colon, ileostomy is preferred. Here, primary ileo-colonic anastomosis is deferred as preservation of ileocecal valve is essential for future growth of the child. Stoma related complications and stoma care remain the issues in these cases especially with ileostomy where effluent is more fluid in nature. To address this issue an early reversal is recommended. Some surgeons prefer primary anastomosis with a proximal covering stoma (colostomy/ ileostomy).

Operative options for isolated RA include transanal end-toend rectorectal anastomosis, mucosal proctectomy and coloanal anastomosis, and posterior sagittal approach $[11,12]$. A very few cases of primary rectorectal/coloanal anastomosis have been reported because of its rarity. Type 1 atresia (rectal membrane) is most common, thus, excision of membrane during PSARP is most suitable option as we did in this series. Practically, we followed three stage procedure (colostomyPSARP with excision of rectal membrane-colostomy closure). The prognosis of CRA is good unless it is associated with other life-threatening congenital anomalies [13]. Symptoms of associated anomalies are sometimes overlooked or may be superimposed by presence of another anomaly. Presence of other alimentary tract atresias like pyloric atresia and multiple colonic atresias and HD always increase the morbidity. Delayed diagnosis increases the risk of intestinal perforation and sepsis $[14,15]$.

\section{Conclusion}

Because of the rarity of the CRA, it can easily have overlooked by any Pediatrician. Most of the times, the cases appear in the emergency for acute intestinal obstruction giving no time to diagnosed preoperatively. A delay in diagnosis is increasing the risk of intestinal perforation, acid-base disturbances, sepsis and so also the mortality. A thorough investigation for associated anomalies should be undertaken before the final surgery. However, prognosis and the long-term outcomes of CRA are satisfactory as the anal canal and lower rectum constituting the lower pouch develop normally and placed normally within well-developed sphincter-muscle complex. Clinically, a colorectal atresia must be differentiated from Hirschsprung's disease, meconium plug syndrome, ileal atresia and other possible causes of neonatal intestinal obstruction. Delay in diagnosis increases the chances of perforation, so also the morbidity.

\section{Disclosure}

The authors declare no conflicts of interest.

\section{Acknowledgement}

Heartly thanks to the Prof. Madhumita Mukhopadhyay [MD], Department of Pathology, Institute of Postgraduate Medical Education and Research (IPGMER), Kolkata, West Bengal, India and to Prof Mala Bhattacharyya [MD], Principal, Dr. B.C. Roy, Post Graduate Institute of Pediatric Sciences (PGIPS), Kolkata, West Bengal, India.

\section{Authors Contributions}

Pankaj Halder is done Literature search \& Editing of manuscript, Rajarshi Kumar is done Literature search, Kartik Chandra Mandal is provided Concept and design, Gobinda Mondal is worked with Literature search and concept, Bidyut Debnath is completed Editing of manuscript, Biswanath Mukhopadhyay is associated Biswanath Mukhopadhyay, Bikram Mandal is provided Concept and design. 


\section{References}

1. Ruggeri G, Libri M, Gargano T, Pavia S, Pasini L, et al. (2009) Congenital colonic stenosis: A case of late-onset. Pediatr Med Chir 31: 130-133.

2. Sharma SP, Upadhyay VD, Pandey A, Gangopadhyay AN (2008) Rectal atresia with rectolabial fistula. J Indian Pediatr Surg 13: 75-76.

3. Etensel B, Temir G, Karkiner A, Melek M, Edirne Y (2005) Atresia of the colon. J Pediatr Surg 40: 1258-1268.

4. Pujar VC, Kurbet S, Kaltari DK (2012) Pyloric atresia in association with multiple colonic atresias in a neonate: An unreported association. J Neonat Surg 1: 6.

5. Mustafa G, Mirza B, Bashir Z, Sheikh A (2010) Delayed recognition of type I sigmoid-colon atresia: The perforated web variety. APSP J Case Rep 1: 5.

6. Cox SG, Numanoglu A, Millar AJ, Rode H (2005) Colonic atresia: Spectrum of presentation and pitfalls in management. A review of 14 cases. Pediatr Surg Int 21: 813-818.

7. Hamid R, Shera AH, Bhat NA, Baba A, Rashid A (2012) Congenital descending colonic stenosis with perforation of transverse colon in a neonate: A case report. J Nepal Paediatr Soc 32: 73-75.
8. Mirza B, Iqbal S, ljaz L (2012) Colonic atresia and stenosis: Our experience. J Neonat Surg 1: 4.

9. Braiek M, Ksia A, Krichen I, Belhassen S, Maazoun K, et al. (2016) An unusual variant of rectal atresia: Diagnosis and management in a neonate. J Neonat Surg 5: 20.

10. Seo T, Ando H, Watanabe Y, Harada T, Ito F, et al. (2002) Colonic atresia and Hirschsprung's disease: Importance of histologic examination of the distal bowel. J Pe-diatr Surg 37: 1-3.

11. Lee $\mathrm{CH}$, Chou MC, Yeh HM (2007) Rectal atresia with rectourethral fistula: A rare anomaly. World J Pediatr 3: 150-151.

12. Kulshrestha S, Gangopadhyay AN, Sahoo SP (1997) An unusual variant of rectal atresia with rectovestibular fistula. J Pediatr Surg 32: 921-922.

13. Chouikh T, Charieg A, Mrad C, Ghorbel S, Saada S, et al. (2014) Congenital colonic atresia: 4 case reports. J Pediatr Neonatal Care 1: 00018.

14. Venkatchalapathy TS, Venkatesh KL (2012) Colonic atresia: A case report. Pediat Therapeut 2: 137- 138.

15. Mansoor H, Kanwal N, Shaukat M (2010) Atresia of the ascending colon: A rarity. APSP J Case Rep 1: 3. 